\title{
From the Adour valley to the Gelise valley (western part of the Gers department): an important occurrence of siliceous raw material of Senonian origin.
}

Marie-Roger Séronie-Vivien, Micheline Séronie-Vivien, Pascal Foucher, Dominique Millet and Françoise Millet

\section{OpenEdition}

\section{Journals}

Electronic version

URL: http://journals.openedition.org/paleo/2474

DOI: $10.4000 /$ paleo. 2474

ISSN: $2101-0420$

\section{Publisher}

SAMRA

Printed version

Date of publication: 15 December 2012

Number of pages: $357-366$

ISSN: $1145-3370$

\section{Electronic reference}

Marie-Roger Séronie-Vivien, Micheline Séronie-Vivien, Pascal Foucher, Dominique Millet and Françoise Millet, « From the Adour valley to the Gelise valley (western part of the Gers department): an important occurrence of siliceous raw material of Senonian origin. », PALEO [Online], 23 | 2012, Online since 18 June 2013, connection on 27 July 2020. URL : http://journals.openedition.org/paleo/2474 ; DOI : https://doi.org/10.4000/paleo.2474

This text was automatically generated on 27 July 2020

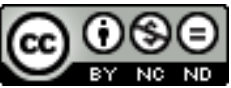

PALEO est mis à disposition selon les termes de la licence Creative Commons Attribution - Pas d'Utilisation Commerciale - Pas de Modification 4.0 International. 


\title{
From the Adour valley to the Gelise valley (western part of the Gers department): an important occurrence of siliceous raw material of Senonian origin.
}

\author{
Marie-Roger Séronie-Vivien, Micheline Séronie-Vivien, Pascal Foucher, \\ Dominique Millet and Françoise Millet
}

The studied region includes the western part of the Gers department and the borders of the neighbouring regions, Landes and Lot-et-Garonne (fig. 1). From a geographical point of view it constitutes the westernmost part of the Lannemezan Plateau. This plateau is made of a huge alluvial detrital fan, a result of the dismantling of the Pyrenees during the Plio-Pleistocene. This sedimentary construction culminates at 660 $\mathrm{m}$ but it lowers quickly in the Gers department from $440 \mathrm{~m}$ in the south to less than $180 / 150 \mathrm{~m}$ in the north (Joanne 1893). Some residual parts of these alluvial sediments were spared by post-depositional erosion at the top of the present-day relief. These natural environments are presently used by agriculture, for vineyards, sunflower, corn or other cereal fields (fig. 2) in which it is possible to collect numerous pebbles extracted from the substratum (fig. 3). Sometimes, ancient local gravel quarries allow stratigraphic observation. 
Figure 1 - Location map of the prospected area.

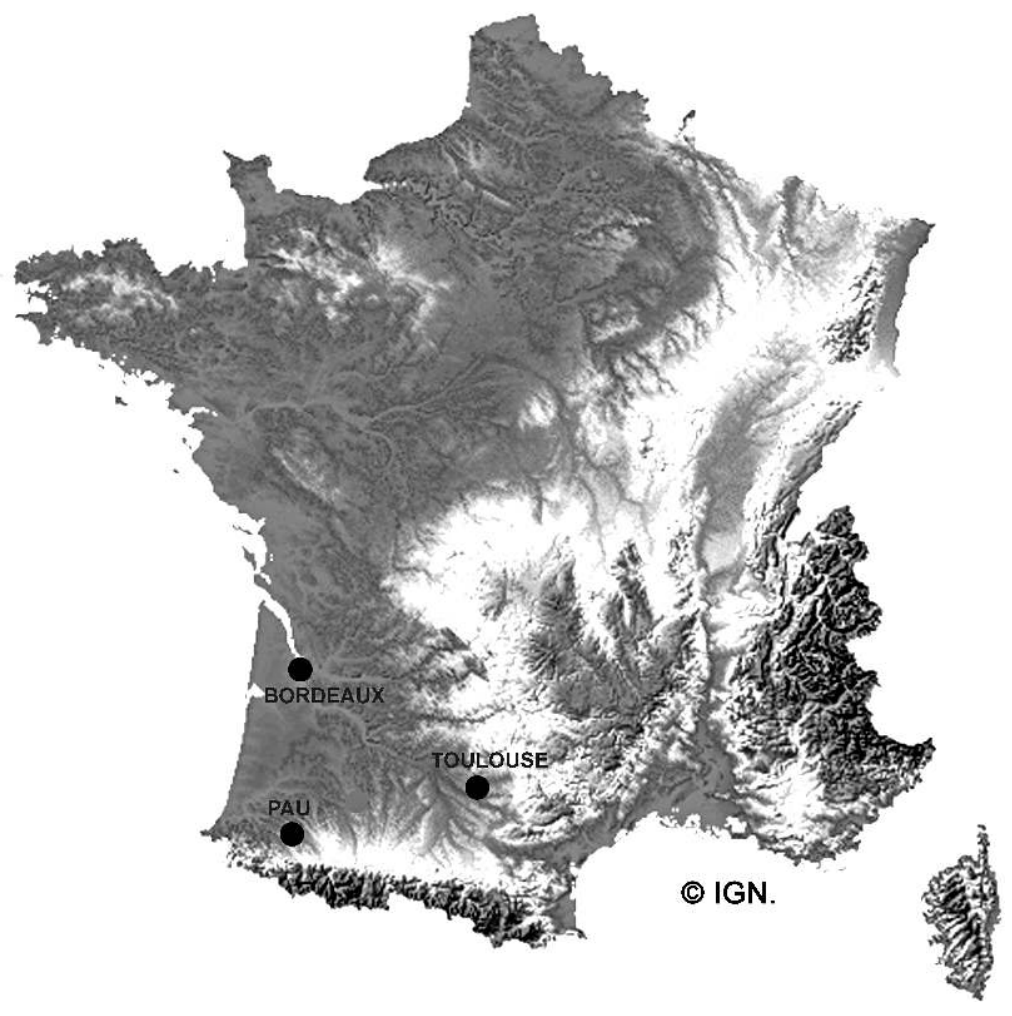

Figure 2 - Example of a ploughed land with flint pebbles.

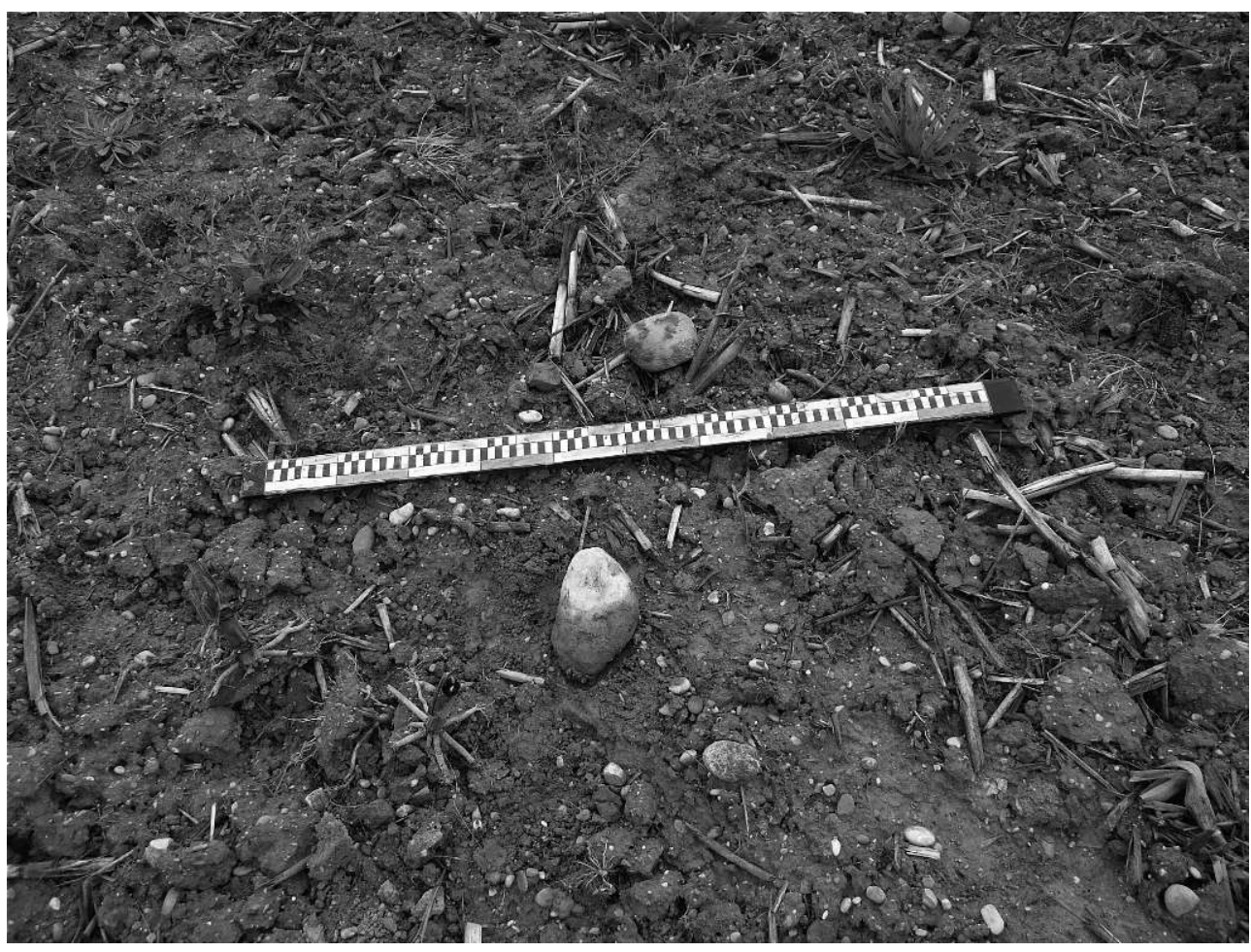


Figure 3 - Front view of a quarry bearing alluvial sediment containing plenty of siliceous pebbles.

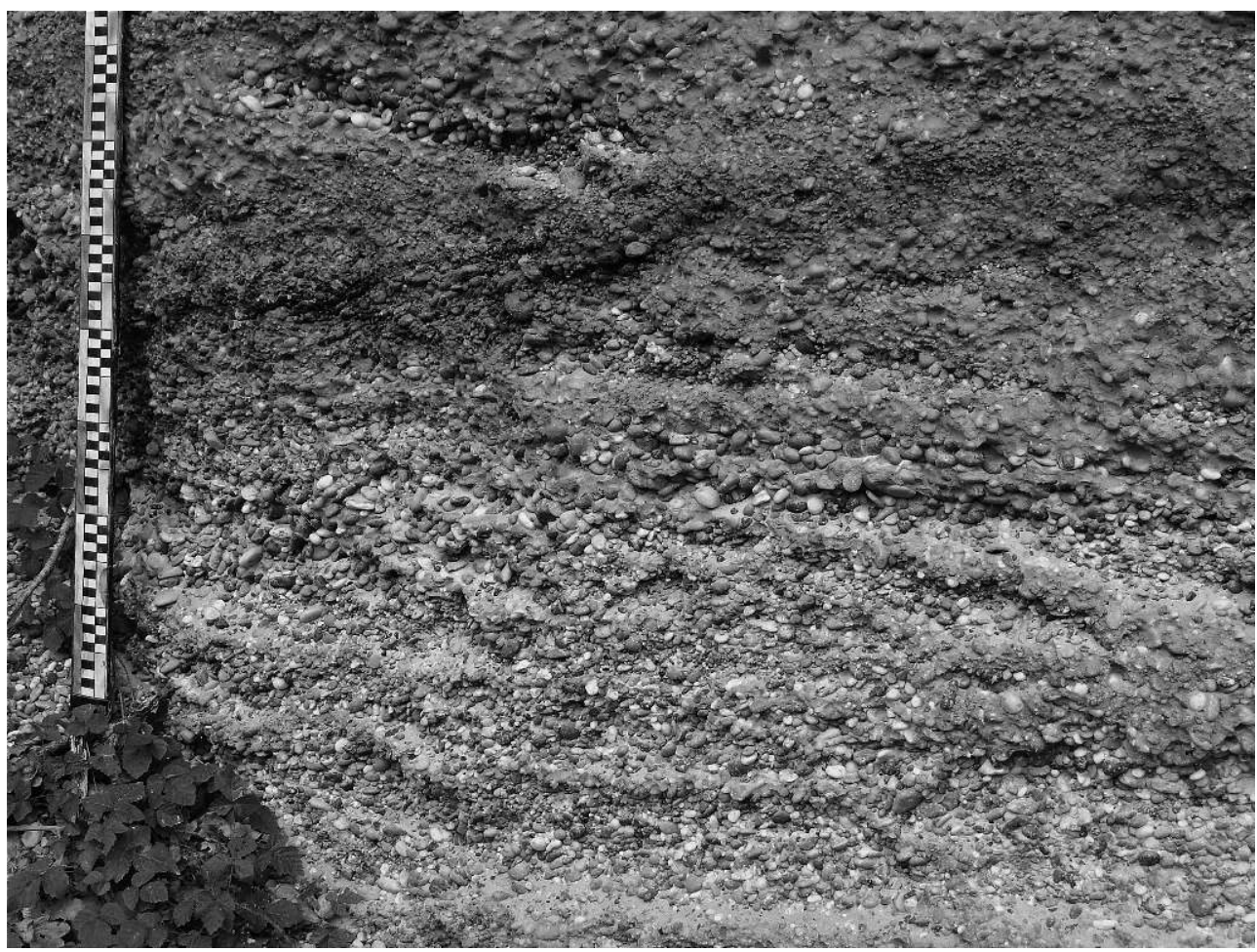

2 Programs of systematic field surveys concerned with the ancient human occupations (Lower and Middle Palaeolithic) in the western part of the Gers (Armagnac) between 1996 and 2006 (Millet et al. 2006) have allowed us to identify the presence of local raw material from outcrops of limited extension (quartzitic sandstones of the Cazalège type, silicification of the Ténarèze) and from exogenous elements (Senonian flint, some with lepidorbitoides). From then, with the discovery of several new flint spreading, we started concentrating on the problematic of the sources (Millet et al. 1999, 2000, 2003, $2004,2005)$ with a systemic approach.

It became necessary to clarify the origin of these clastic elements in Senonian flint, amongst others. Several hypotheses were possible:

- Introduction from peripheral sources to the studied region

- Local outputs on anticlines at the heart of the Upper Cretaceous

- Presence in derivative position in quaternary alluvial deposits

- Occasional concentrations in the local Pliocene deposits (striated clay / pebble clay) making detrital glacis that are more and more residual from the south to the north of the studied region.

4 The absence of showing or sub-showing Senonian eliminates the second hypothesis (analysis of about one hundred test-pit results between Vic-en-Bigorre and Eauze). The distribution of the areas that gave positive samples in the Adour Valley (Riscle municipality) indicates potentialities within the alluvial deposits associated with the Middle Pleistocene (regular blocks with fluviatile neocortex). Toward the north, outside of the alluvial corridor, the blocks are often found in the alterites that seal off the heads of the small valleys at the foot of the pebble clay formations and in the palaeochannels that incise the top of the tan sands between Gélise and Midou (fig. 4). It 
was becoming obvious that at least two local sources were existing that excluded any systematic intrusion of anthropic nature from the peripheral regions.

Figure 4 - Location map showing the sampling areas (croix noires).

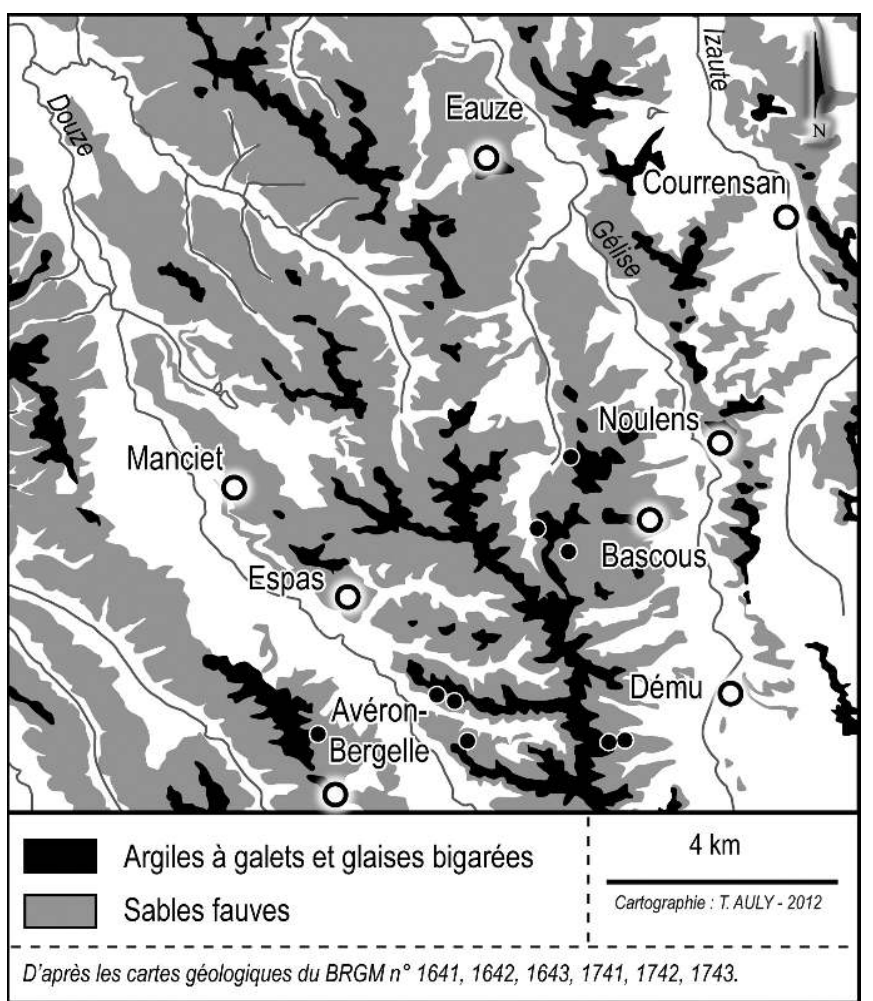

5 The dynamic geomorphological results that will serve to elaborate a scenario about the setting up of these Senonian flints "placers" favours a diffusion by successive transits of these materials in a medium to weak fluviatile system (deposits in anastomosed and braided channels) during the setting up of the pebble clay/ striated clay formations (Pliocene). These deposits are residualized by erosion. They constitute the distal lobes of the detrital accumulation glacis of pre-piedmont centred on the south west of the Gers. Although primary sources are not presently identified, they can only by localised upstream the large alluvial fans of Ger and of the Lannemezan.

6 From these geomorphological observations, surface surveying was done. It allowed collecting 290 pebbles that were submitted to a petrographic study conducted according to our usual method (Séronie-Vivien M. and M.R. 1987; Séronie-Vivien M.R. 2010). In parallel, it was possible to analyse 132 artefacts (Upper Palaeolithic to Neolithic) coming from the same region that were kindly lent by their owners. The petrographic inventory of the pebbles led to the description and characterization of 19 lithological types of flint. It was possible to offer a petrographic attribution of these types with more or less precision according to the abundance of microfauna contained in the rocks. The results were correlated with the available geological data, of surface and sub-surface, in order to make hypotheses on the origin of these flints.

7 One must recall, however, that for the Prehistorian, this raw material source is seldom taken into account, as his/her interest is essentially the geography of raw material outcrops as it could have existed at the time of collecting by Prehistoric People. The geological context remains decisive for the understanding of the setting up of the Plio- 
Pleistocene alluvial spreading that we studied and that are found on a large part of the Gers department.

\section{1 - Characterization of flint pebbles}

\section{1 - The Adour Valley}

The prospected region in the Adour valley is located downstream up to Aire-sur-Adour and stretches upstream on a large part of the Riscle municipality (Riscle, Saint-Mont, Labarthète, Aurensan, Viella and Lelin-Lapujolle). In total, 75 pebbles were taken and analysed. They came from surface surveying in cultivated lands (corn fields, vineyards, etc.).

9 On the left bank of the Adour (50 samples), three lithological types of flint were recognised:

- Type A: Homogeneous flint, mudstone texture, microcrystalline cement, with numerous recrystallisation zones (chalcedony), some fibrous elements (plant). Although no characteristic fossils were found, it is likely that this type of flint is connected to the Cenozoic.

- Type Ba: Flint with homogenous structure, wackestone texture, with angular intraclasts and a rather abundant microfauna: Lepidorbitoides socialis, Lepidorbitoides $s p$, Orbitoids, Meandropsina vidal (fig. 5c), Siderolites vidali (fig.5e), Fascispira sp. (fig 5g), spicules, and quite rare dasycladaceae. The faunal assemblage is typical of the Upper Maastrichtian of the Pyrenean piedmont.

- Type Bb: Flint with homogenous structure, mudstone texture, with numerous pellets, quite abundant microfauna: Lepidorbitoides sp., Clypeorbis mamillata (fig.5a) Siderolites vidali, rather rare Pithonella (fig.5h), spicules, rare dasycladaceae.

Except for the flint that appears to be tertiary (type A) all the other pebbles would be from the Upper Maastrichtian. The differences between the $\mathrm{Ba}$ and $\mathrm{Bb}$ types are very small: the biotopes appear to be the same and the noted variations only show a difference in the energy level.

10 On the right bank of the Adour, only two sites were spotted by surveying (LelinLapujolle municipality). It was possible to distinguish five different types from 25 pebbles collected on the surface:

- Type C: Flint with homogeneous structure, mudstone texture with rare pellets and some rounded intraclasts $(300 / 500 \mu)$. The microfauna is made of Lepidorbitoides sp., rather rare Siderolites, bryozoans and spicules, plus some dasycladales.

-Type D: Flint with homogeneous structure, mudstone texture with numerous to very numerous pellets and some rounded intraclasts. The microfauna is little diversified (Lepidorbitoides and spicules).

- Type E: Flint with homogeneous structure, mudstone texture with rare pellets and a microcrystalline matrix. The microfauna is restricted to spicules and some rare bryozoans. The microflora is composed of dasycladales stems. The absence of lepidorbitoides can be noted.

- Type F: Flint with homogeneous structure, mudstone texture with some pellets. The microfauna does not contain lepidorbitoides but only spicules and rare bryozoans. Some fragments of dasycladaceae underline the infra coastal character of the deposit environment. 
- Type G: Flint with a microstratified structure with an apparent grano-classification and a mudstone texture with pellets and very numerous spicules, often oriented.

11 The types $\mathrm{C}$ and $\mathrm{D}$, similar to the type $\mathrm{Bb}$ of the previous series, are doubtlessly attributable to formations of the Upper Maastrichtian. They originate from an infra coastal sedimentation area submitted to a low agitation of the water.

In types $\mathrm{E}$ and $\mathrm{F}$, lepidorbitoides were not found and the microfauna did not show any element allowing a precise dating; they could be connected to the Senonian formations (Coniacian to Campanian) of the Pyrenean piedmont.

13 Finally, type $\mathrm{G}$, by its structure as well as by the grano-classification of the sediment, shows all the characteristics of a Pyrenean Flysch (Barragué et al. 2001).

One can note that on a total of 75 studied pebbles coming from the ancient alluvial deposits of the Adour, 42 could be attributed to the Upper Maastrichtian (56 \%), 31 to the Senonian (41\%), one to the Cretaceous Flysch and one to the Cenozoic.

\section{2 - The tributary valleys of the Adour. Izaute, Midour, Midouzon and Douze}

To the north of the Adour valley, a whole range of watercourses are draining the northwestern flank of the alluvial fan of the Lannemezan. These rivers, firstly oriented towards the north, then change direction toward the west and become tributaries of the Adour River, often through the intermediary of the Midouze River. The surveys were carried out on cultivated lands in order to look for flint pebbles in this part of the Gers department. The municipalities of Bétous, Cravencères, Averon-Bergelle, Aignan, Séailles, Espas, Demu (pro parte) were explored. Ancient quarries (gravel pits) were also studied and sampled; they were operated on the municipalities of Espas and AveronBergelle. In total, 170 alluvial pebbles have been collected and analysed. The petrographic study of the samples led to distinguish, besides the types already described from the material coming from the Adour, eight new lithological types that can be described as follows:

- Type H: Flint with homogeneous structure, grainstone texture with large rounded intraclasts $(300 / 500 \mu)$, rather poor microfauna: rare spicules, some rotalidae foraminifera.

- Type I: Flint with homogeneous structure, mudstone texture with rare pellets, aggregates (lumps), little diversified microfauna: spicules, rather frequent pithonella.

- Type J: Flint with homogeneous structure, mudstone texture with pellets, rare rounded intraclasts, rather frequent bioclasts, presence of spicules and dasycladale algae (Neomerys see cretacea, fig.5b).

- Type K: Flint with homogeneous structure, mudstone texture with very abundant pellets and small intraclasts, frequent spicules.

- Type L: Flint with homogeneous structure, wackestone texture, with some pellets and rounded intraclasts $(300 \mu)$, some lepidorbitoides (Lepidorbitoides socialis).

-<\#ITALIQUES\#></\#ITALIQUES\#>Type M: Flint with homogeneous structure, wackestone texture with some pellets and rounded intraclasts, rather rare microfauna (spicules).

- Type N: Flint with homogeneous structure, packstone texture with large rounded intraclasts $(500 \mu)$, rare spicules with some rotalidae and valvulinidae.

- Type 0: Flint with homogeneous structure, mudstone texture with rare pellets, some spicules. Large re-crystallisation zone disturb the observation. 
Out of these new types only one (Type L) can be attributed to the Upper Maastrichtian. All the others, from type $\mathrm{H}$ to type $\mathrm{O}$, are attached to the Senonian in the broad sense because of a lack of characteristic fossils. Two types ( $\mathrm{H}$ and $\mathrm{N}$ ) distinguish themselves by textures that indicate sedimentation in an area of high energy, clearly different from the low energy environment that characterises the other structures, usually mudstone and more rarely wackestone. Out of the 170 studied pebbles, 63 (37\%) would be from Maastrichtian origin, while 106 could be attributed to Senonian formations (from the Coniacian to the Campanian) and one flint to the Pyrenean Flysch.

Figure 5 - Exemples de microfaune et de microflore (l'échelle de $1 \mathrm{~mm}$ est indiquée par un trait noir, sauf pour le $\mathrm{n}^{\circ} 5 \mathrm{~h}$ où elle ne représente que $0,5 \mathrm{~mm}$ ).

5a - Clypeorbis mamillata

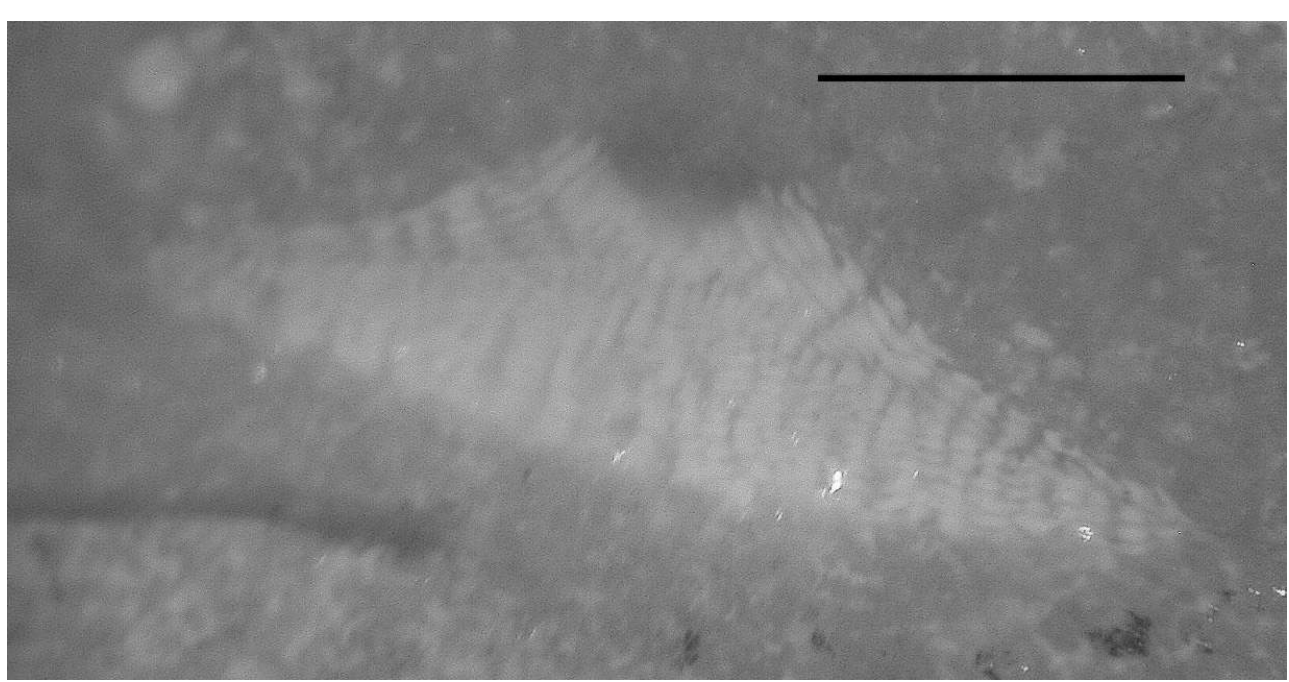


$5 b$ - Algue dasycladale - section longitudinale

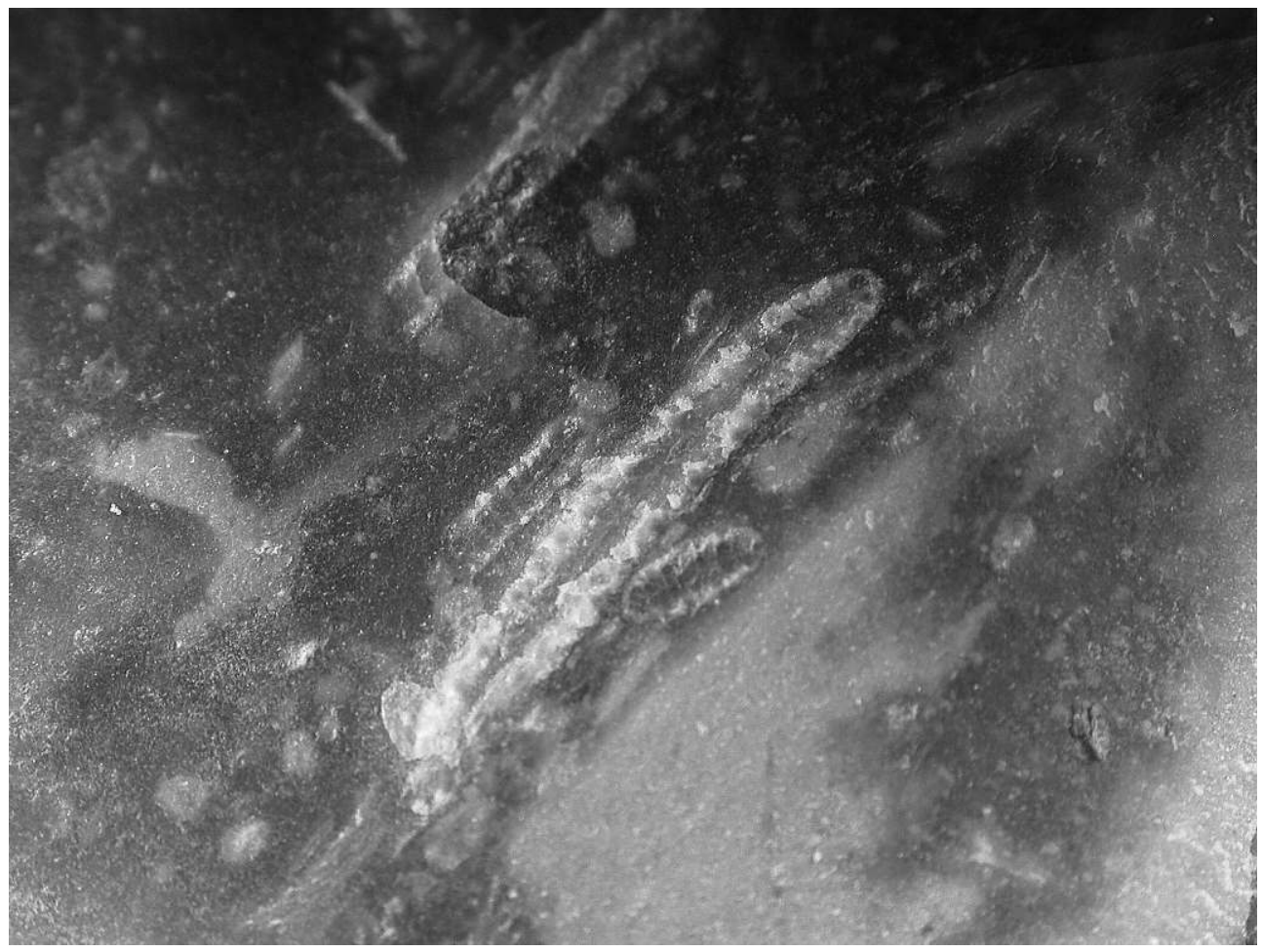

\section{5c - Meandropsina aff. Vidali}

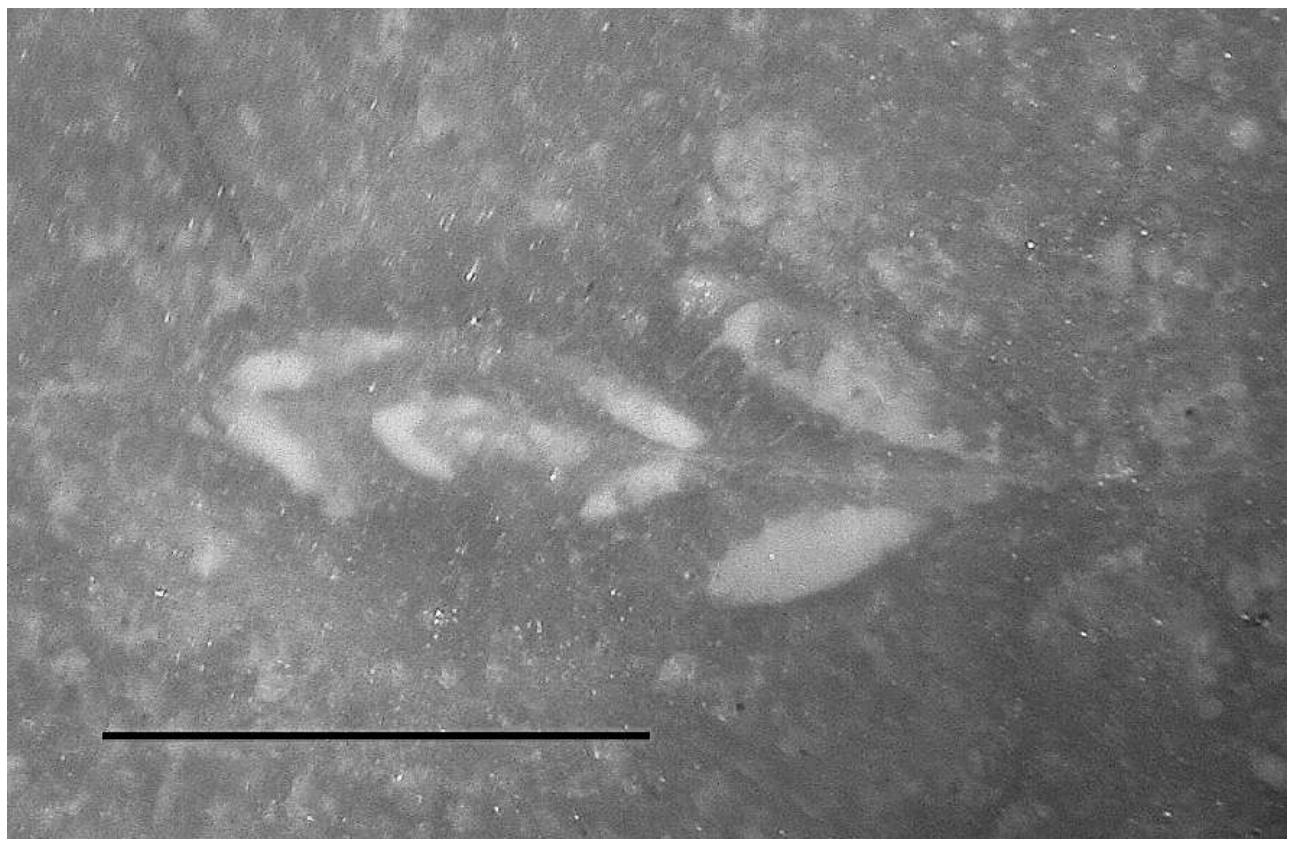


5d - Algue : dasycladacea : cf. Cylindroporella

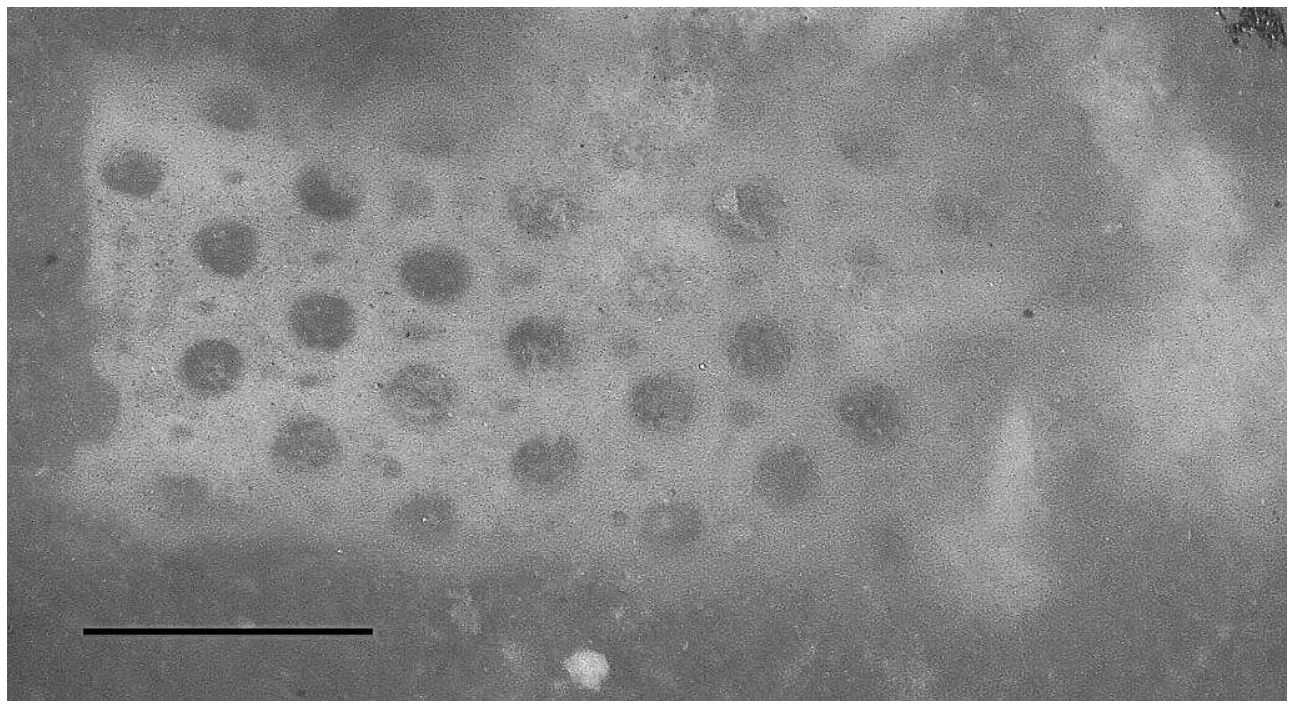

\section{$5 e-$ Siderolites vidali}

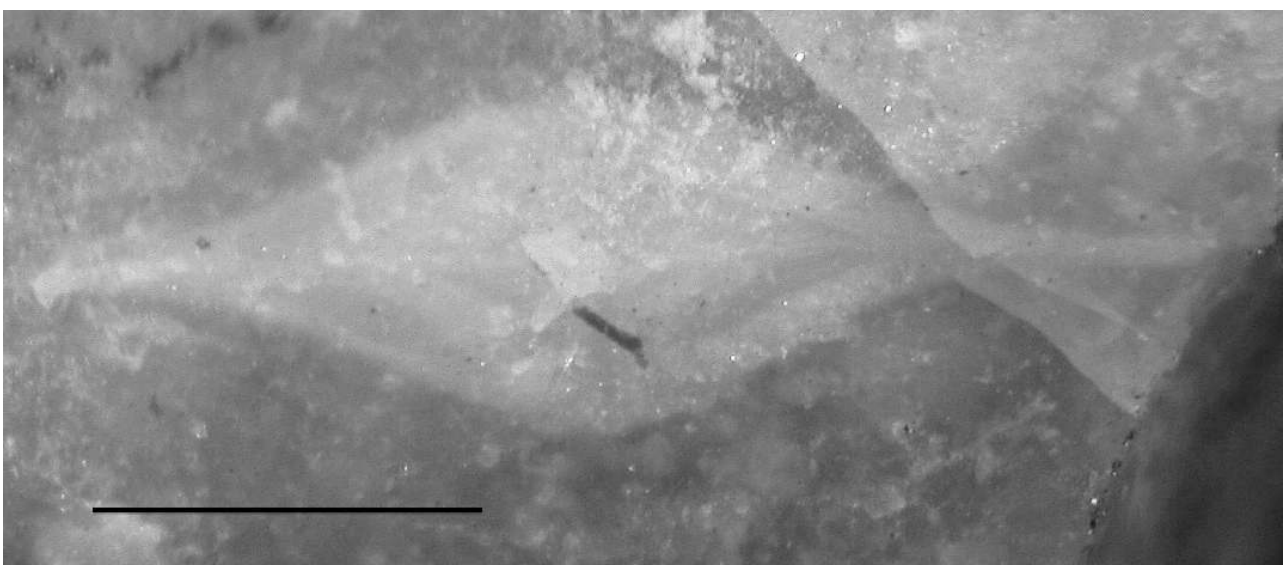


$5 f-$ Lepidorbitoides socialis

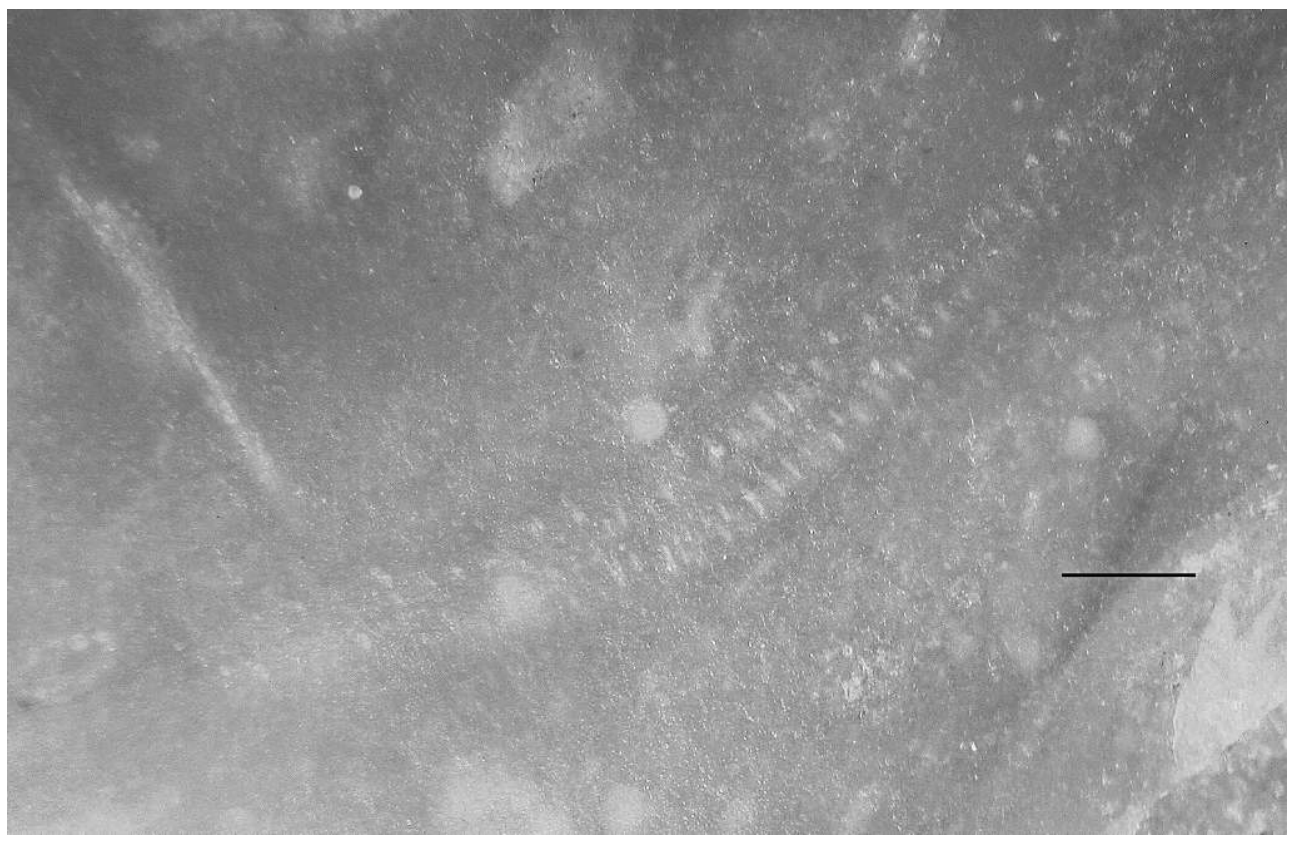

$5 g$ - Fascispira sp.

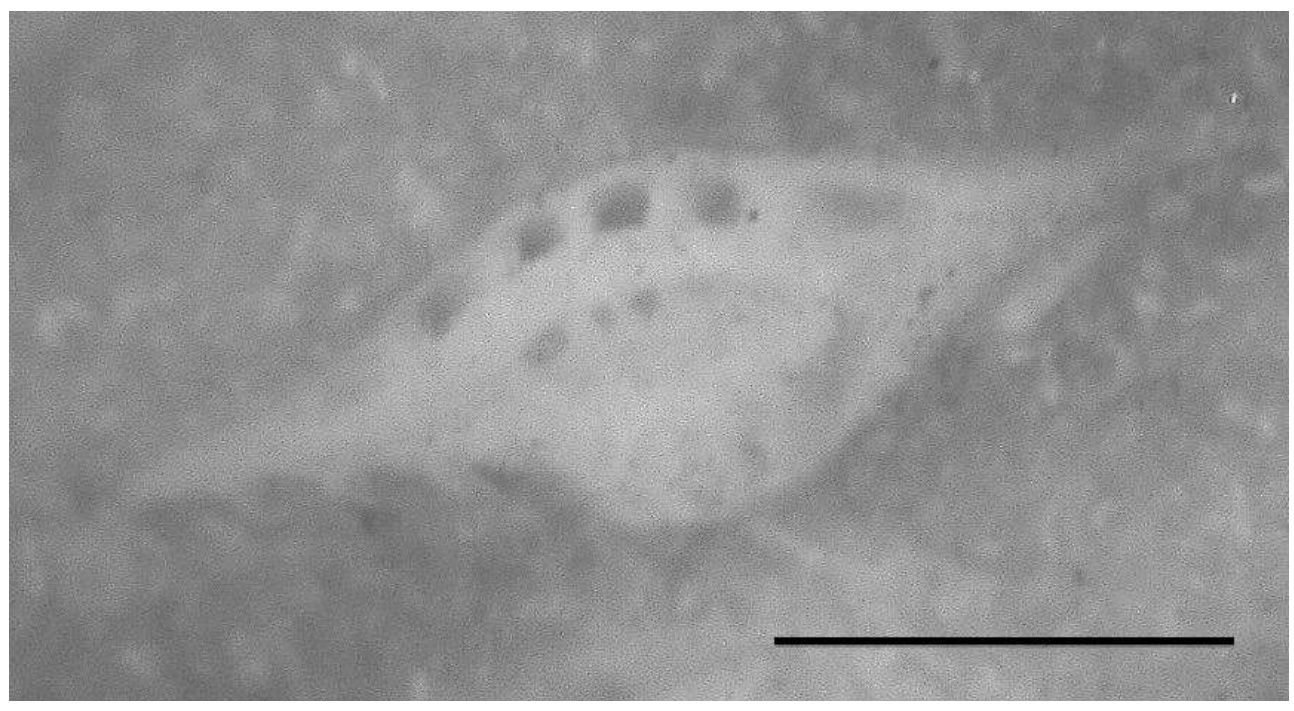




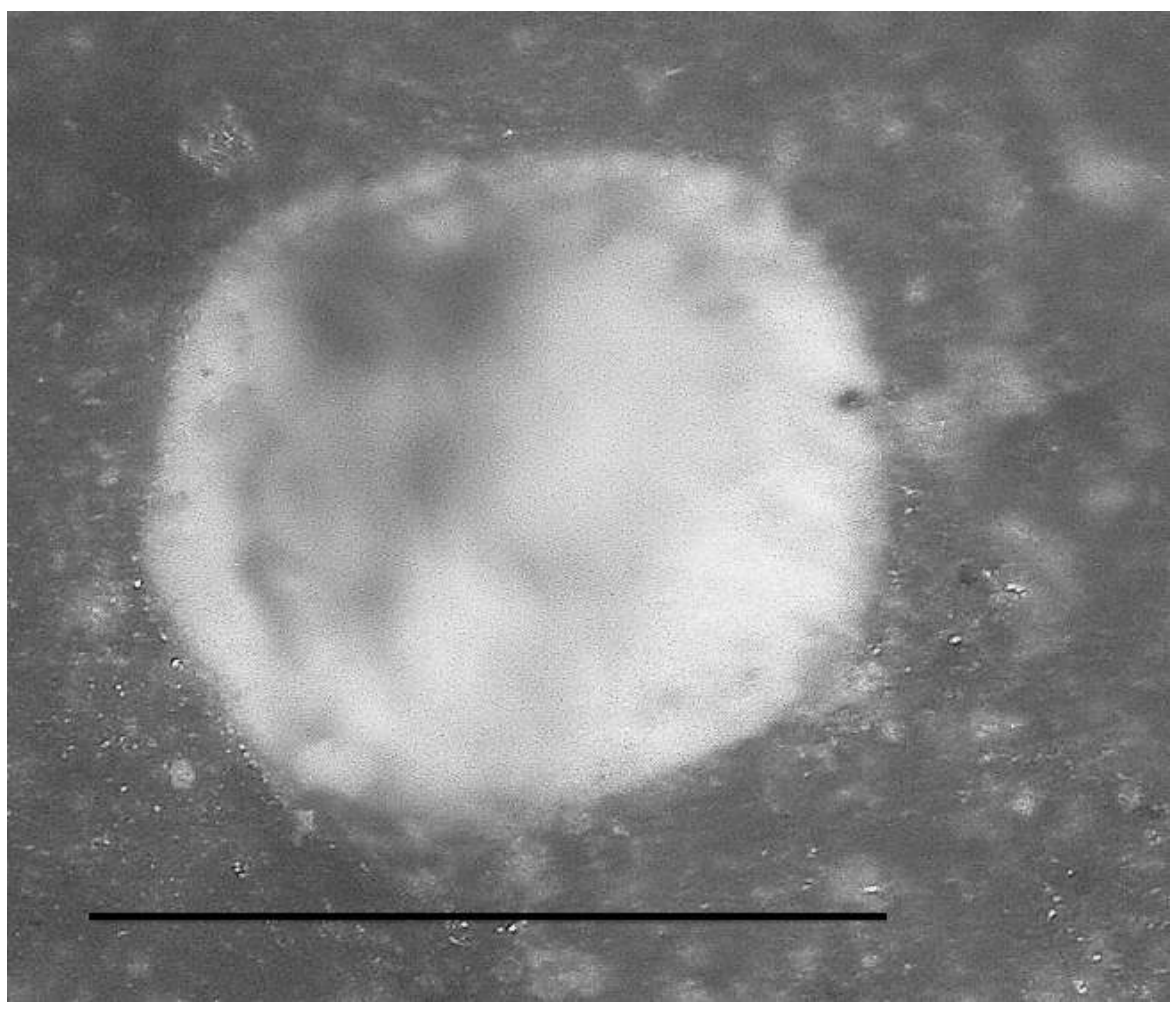

\section{3 - The Gélise valley}

17 The Gélise River is not a tributary of the Adour but an affluent of the Garonne after its confluence with the Baïse. Its trajectory is markedly south- north but it does not inflect towards the West as all the previously mentioned watercourses.

The surveyed area is situated in the middle of its course on the municipalities of Dému and Bascous. It is in particular around this last agglomeration that numerous ancient gravel pits exist, most of the time abandoned, in which we were able to sample an abundant material. We sampled 45 pebbles from these sites. Three new types were defined:

- Type P: Flint with homogenous structure, wackestone texture with pellets and angular intraclasts, lamellibranches, with no or little microfauna.

- Type Q: Flint with microstratified structure, grainstone texture with small $(50 \mu)$ to mediumsized $(300 \mu)$ intraclasts, calibrated and grano-classified.

- Type R: Flint with homogenous structure, packstone texture with frequent rounded intraclasts, rather numerous lepidorbitoides (Lepidorbitoides socialis, fig.5f).

Among the group of 45 studied pebbles, 25 are attributable to the Senonian, 19 (42\%) to the Maastrichtian and one to the Pyrenean Flysch. 


\section{2 - Petrographic study of knapped flint from the same region}

\section{1 - The Adour Valley}

Very few artefacts (Middle and Upper Palaeolithic, Neolithic) could be studied. The were coming from Riscle, Saint-Mont and Lelin-Lapujolle. They were all Maastrichtian in age and of the same type as most of the pebbles (type $\mathrm{Bb}$ ).

\section{2 - The tributary valleys to the Adour}

21 Among the material from ancient surveying carried out by G. Duclos (Duclos 1991) and kept in the Eauze museum some artefacts were indeed found (Middle Palaeolithic to Neolithic) that used the sampled materials. A petrographic study of these collections could be planned.

\section{3 - The Gélise Valley}

- Municipality of Parleboscq (Lot-et-Garonne): The surface surveying for pebbles allowed us to collect 14 artefacts (Upper Palaeolithic to Neolithic). Among these 14 items, 11 are Maastrichtian flint (type $\mathrm{Bb}$ and $\mathrm{D}$ ), three others flints are rocks with mudstone texture and pellets containing spicules (likely Senonian).

- Municipality of Sainte-Maure-de-Peyrac (Lot-et-Garonne): A local owner, Mr Dufaut, kindly let us study his collection of flint from a petrographic point of view. It contains objects from the Neolithic and the Upper Palaeolithic (49 studied items) and from the Lower or Middle Palaeolithic (66 studied items). The Upper Palaeolithic/ Neolithic flints included 22 objects of Maastrichtian age (type D), the 27 others could be attributed to the Senonian (Coniacian/Campanian - types F, J, K). Amongst the 66 Middle/ Lower Palaeolithic artefacts only three are made of Maastrichtian flint (types Ba and R). All the others were made out of continental flints from extremely local origin, Cenozoic in age. A striking contrast can be seen in the materials from distinct geological strata: flint from the local Agen area continental Cenozoic and Mesozoic exogenous flint pebbles. We noted the systematic use of a lake flint from the Agen region (the Auvignon basin) with a rather poor productivity in the ancient series; another quality comes from the valley around the Ténarèze (Auzoue basin) in which outcrops of voluminous blocks of continental silicifications led to a rather poor debitage. Besides, smaller flint pebbles do exist: they were collected in the ancient alluvial deposits of the Gélise basin and allowed a finer debitage and the obtaining of more delicate tools, small blades for example (Upper Palaeolithic to Neolithic). In this last case, although the total number of studied objects is rather low (115), the global proportion of Maastrichtian flint used is $48 \%$, which is in the same order as what has been observed for the river pebbles of the Lannemezan Plateau that we surveyed (37 to $56 \%$ ).

- Municipality of Nérac (Lot-et-Garonne): a collection of flints from a possibly Azilian site is presently being studied. Out of the 20 studied samples, nine are Maastrichtian in age, the others being Senonian. 


\section{4 - The Baïse Valley} study of 49 tools from the site of La Brette in Condom. Out of this sample, 19 flints are Maastrichtian, 20 are Senonian and three from the continental Tertiary.

\section{3 - Sedimentological and palaeogeographical interpretation}

The 19 described petrographic types can be distributed under a certain number of groups according to their common characteristics (structure, texture, petrographic components, microfauna, flora, etc.) From this classification, a palaeogeographical interpretation will be offered for each case.

\section{1 - Cenozoic}

Group I (type I)

Flint with homogenous structure, mudstone texture, without trace of clast or fossil except for some vegetal fibre fragments (see phragmites and/or typha). This microgroup is little significant; we can only assume a lake sedimentation, probably in the Cenozoic.

Group II (types $G$ and Q)

Flint with microstratified structure with a grano-classification of the detrital elements. These criteria are specific of a particular sedimentation found in the Flysch type of deposits whether in the Alps or in the Pyrenees. Therefore this flint can be traced back to the edge of the Pyrenean front. We do know this type of flint in the Hibarette and the Montgaillard regions (Barrague et al. 2001) but other outcrops of this flint do exist all along the Pyrenean Flysch.

\section{2 - Upper Maastrichtian}

Group III (types Bb, C, and D)

Flint with an homogenous structure, mudstone texture with frequent to very frequent pellets containing a rather abundant Maastrichtian fauna made of orbitoides (Lepidorbitoides minor, Lepidorbitoides socialis, Clupeorbis mamillata), siderolites (Siderolites vidali), lepispheres (Pithonella sp.) and some dasycladales algae (Thaumatoporella, Salpingoporella, Cylindroporella) (fig.5d), etc.

The types D and L, very similar, differ however by a wackestone texture that witnesses a slightly higher - but still low- level of energy of the waters. These flints appear to have deposited in a low energy marine environment, the place of a biocenose that was rich in organisms generally associated to a little agitated medio-coastal environment. This group is typical of the Upper Maastrichtian sedimentation of the Southern Pyrenees platform (Lacq basin).

Flint with a homogenous structure, packstone texture with large rounded intraclasts 
and a microfauna dominated by numerous Lepidorbitoides socialis. This rock indicates a clearly more agitated environment than the previous one with elements that underwent an erosive action and the establishment of a nearly monospecific biotope. This sediment can be attributed to a medio-coastal environment submitted whether to the action of very active currents whether to tidal action.

\section{3 - Senonian (from the Coniacian to the lower Maastrichtian)}

Group V (Types E, F, I, J, K, O)

Flint with homogenous structure, mudstone texture with pellets, a more or less abundant matrix, and little diversified microfauna made of sponges spicules and rare bryozoans, some pithonella and dasycladale algae (Salpingoporella and Neomerys see cretacea). Some reorganization traces (burrows, some "lumps"). These observations lead to consider a sedimentation of a calm environment of the infra-coastal area, or even circa-coastal. No microfossils allows situating stratigraphically these levels, the faunal group only leads to suggesting a Senonian age, possibly in its upper part (CampanianMaastrichtian) (Lacombe 1998).

\section{Group VI (types H, N)}

Flint with homogenous structure, grainstone or packstone texture, with rounded intraclasts up to $500 \mu$. The microfauna is exclusively made of rotalidae and valvulinidae as wall as rare spicules. These characteristics indicate a high energy marine environment and a probably circa-coastal deposit environment, but the microfauna does not allow a precise stratigraphic attribution.

\section{4 - Discussion and conclusion}

The study shows that the detrital fan of the Lannemezan is partly made of fluviatile alluvial deposits that contain Senonian flint pebbles (in the broad sense). These sediments contain elements of sufficient size to use as raw material as early as the Palaeolithic. The detailed analysis of the alluvial material showed that:

- A very small quantity of flint from lake origin can be attributed to the Cenozoic;

- Flint that could come from the Pyrenean Flysch formation is found, but rare. The very low proportion ( $0.2 \%)$ of this type of rock underlines the low regional extension of this type of outcrops, which were affected by the erosion of the Lannmezan fan. However, one must remember that these elements were collected very much to the north of the studied region, on the middle course of the Gélise;

- Out of the 290 raw flint analysed, 130 were from the Upper Maastrichtian (45\%) with relatively close values in the different valleys (56\%, $37 \%, 42 \%)$. This result, together with the comparison of the geographical distribution of the primary types, indicates supplying from a quite reduced area;

- The inventories carried out emphasize a notable proportion of the lithics as coming from the Upper Cretaceous. It remains that the initial source of these rocks remains unknown. Mesozoic structures that are still outcropping and that were at the source of some accumulations of alluvial flint are known to the east of the Pyrenees (Petites Pyrenees) and to the West (Chalosse and west-Béarn). One can assume that the pre-Pyrenean folding is continuing all along the orogenic chain, ahead of the Northern Pyrenees front and that the Lannemezan fan eroded or covered part of it between the Ariège and the Garonne. 
Indications collected in subsurface by petroleum research would confirm this pattern. Besides, the outcrops of Cézan-Lavardens (Gers) and for example of Créon-des-Landes teach us that pre-orogenic folding is frequent in the region and is not found at a great depth. As previously indicated, the geological origin of these lithic raw materials does not directly concern prehistorian researchers. Their interest focuses on the present (or sub-present) geographical distribution of the Plio-Pleistocene sediments that remain their centre of interest.

As a conclusion, one can retain that the alluvial sediments of the Lannemezan plateau, produced by the fluvio-glacial erosion that affected the range of the Pyrenean piedmont contain an abundant lithic material from the Upper Cretaceous. It has been a source for collecting at least since the Upper Palaeolithic. This result would need to be taken into consideration in any new study of the petrography of lithic raw materials in Aquitaine. The "Petites Pyrénées" and the Chalosse are not anymore the only possible sources for these flints, especially those of the Upper Maastrichtian. Recent observations (Lelouvier et al. 2012; Colonge et al. 2011) in neighbouring sites confirm this interpretation by indicating discoveries of flint with Lepidorbitoides (low valley of the Douze) or with a "probably Maastrichtian" age in the Gers valley, that is to say in one case upstream from our study area and in the other case, in a more eastern part of the Lannemezan in very close palaeotopographical conditions.

\section{BIBLIOGRAPHY}

BARRAGUÉ J. et E., JARRY M., FOUCHER P., SIMONNET R. 2001 - Le silex du Flysch de Montgaillard et son exploitation sur les ateliers du Paléolithique supérieur à Hibarette (Hautes-Pyrénées), Paleo, 13, p. 29-51, 13 fig., 3 tabl.

COLONGE D., CHALARD P., BILOTTE M., DUCASSE S., PLATEL J.-P. 2011 - Nouvelle découverte d'un gîte à silex à Lepidorbitoïdes dans le Sud-Ouest de la France (Saint-Aubin, Gers) et implications archéologiques, Bulletin de la Société préhistorique française, 108, 3, p. 561-564.

DUCLOS G. 1991 - Eauze, de mémoire d'homme et de pierres, p.21-43, In : Eauze Terre d'Histoire par Bordes M., Courtes G., Duclos G., Gugole J., Lapart J., Legrand F., Loubes G., Pedussaut P. et Vayrette A., Nogaro, Imp. Dauba, 287 p., ill.

JOANNE A. 1893 - Géographie du département du Gers. Hachette édit. 54 p., 1 carte.

LACOMBE S. 1998 - Stratégie d'approvisionnement en silex au Tardiglaciaire. L'exemple des Pyrénées centrales françaises. Bulletin Société Préhistorique Ariège-Pyrénées, 53, 223-266.

LELOUVIER L.A., BOSC-ZANARO B., BRUXELLES L., CHALARD P., JARRY M. 2012 - En Vignes, une halte d'approvisionnement en silex au Tardiglaciaire dans le Gers (France). Bulletin de la Société Préhistorique française, 109, 1, 223-266.

MILLET D. 2000 - Les matières premières siliceuses de l'interfluve Adour/Garonne : les gîtes à grès en Bas-Armagnac (Gers). In : Coord.1999 : F. Briois : Lithothèque des matières premières siliceuses, région Midi-Pyrénées, Rapport année 1999, 127-147. 
MILLET D. et MILLET F. 2006 - Technocomplexes à galets taillés du Paléolithique inférieur en BasArmagnac et Vic-Bilh (Gers). In : Préhistoire du Bassin de l'Adour, Colloque de Saint-Etienne de Baïgorry (12 janvier 2002)- Dir. Cl. Chauchat et al. - Comité IZPEGI, 9-32.

MILLET D. et MILLET F. 1996 - Les formations alluviales du Pleistocène inférieur et moyen des vallées de l'Adour et de la Garonne. Premières aires d'activités humaines. Prospections thématiques (Gers et Haute-Garonne). SRA Midi-Pyrénées DFS de prospection thématiques, N.D. 55 p., 31 ill.

MILLET D., JAUBERT J., DUCLOS G., CAPDEVILLE J.-P. et al. 1999 - Une exploitation paléolithique de grès en Armagnac : le site de Cazalège à Castelnau d'Auzan (Gers). Paleo, 11, 43-70.

MILLET D., MILLET F., CAPDEVILLE J.-P., MERCADAL P. 2003 - Technocomplexes à galets taillés du Paléolithique inférieur en Aquitaine méridiobale : moyenne vallée de l'Adour (Vic-Bilh et BasArmagnac). DFS de prospection thématique. Opération 101-103, 104 p., 28 pl.

MILLET D., MILLET F., DUFAUT H. 2005 - Modalités de l'anthropisation paléolithique du Bassin moyen de la Gélise en Gabardan (Landes) et Albret méridional (Lot-et-Garonne).Archéologie des Pyrénées occidentales et des Landes, t. 24, 73-84.

SÉRONIE-VIVIEN M. et SÉRONIE-VIVIEN M.R. 1987 - Les silex du Mésozoïque nord-aquitain. Approche géologique de l'étude des silex pour servir à la recherche préhistorique. Suppl.t. XV Bulletin de la Société Linnéenne de Bordeaux, 135 p.

SÉRONIE-VIVIEN M.R., SÉRONIE-VIVIEN M., AFFOLTER J., DELVIGNE V., PIBOULE M., RAYNAL J.P., MONCEL M.H., TUFFERY C., TURQ A., MORALA A., ORTEGA D., X., REY M., MANGADO X., THIRY M., FOUCHER P., MILLET D. MILLET F., DUCLOS G., SCHMIDT P., FRÖHLICH F., DELAGE C., NORMAND

C. 2010 - Une Approche vers la détermination des silex : la pétrographie sédimentaire. - $P$. Fernandes (dir.) : Rapport d'activité du PCR « Réseau des lithothèques en Rhone-Alpes », SRA RhôneAlpes, 1 vol. 233 p.

\section{ABSTRACTS}

This study refers the western part of the "Gers department" which covers the Adour valley, its tributaries (Izaute, Midour and Douze) and the Gélise valley. A geological study was carried out from 2010 to 2012. It allowed us to collect 290 alluvial siliceous pebbles from the Plio-Pleistocene sediments. At the same time, 132 flint artefacts from prehistoric sources in the Gers (Upper Palaeolithic) were collected. Petrographic, sedimentological and palaeontological studies were carried out. They allowed us to distinguish 19 lithological types:

- 1 related to the Cenozoic formation;

- 2 associated with Flysch deposits from the Pyrenean orogenic belt;

- 10 attributed to the Senonian age (from the Coniacian to the Campanian);

- 6 imputed to the Upper Maastrichtian with Lepidorbitoides.

Then these types were brought together into six groups that show their stratigraphic positions and their palaeogeographic environments at different time periods.

$-0.2 \%$ of the alluvial pebbles were related to the Pyrenean Flysch;

- $45 \%$ were of Upper Maastrichtian age (Lepidorbitoides);

- $54 \%$ were of Senonian age (Coniacian to Middle Maastrichtian).

The artefacts collected in the same region show a very similar proportion of siliceous pebbles (49 $\%$ of Maastrichtian with Lepidorbitoides).

The result of this study is that, up to now, the western part of the Lannemezan Plateau includes alluvial areas of Plio-Pleistocene age, containing a large amount of flint pebbles of Upper 
Cretaceous age (Senonian and Maastrichtian). The gathering of this siliceous raw material by Palaeolithic communities is obvious. The identification of a new lithic raw material located in the southern Aquitaine Basin will have to be taken into account, while former interpretations probably have to be amended.

INDEX

Keywords: Gers department, Petrography, Sedimentology, Micropalaeontology, Senonian, Upper Maastrichtian, Upper Palaeolithic

\section{AUTHORS}

\section{MARIE-ROGER SÉRONIE-VIVIEN}

125 avenue d'Eysines, 33110 Le Bouscat, France - rseronie@club-internet.fr.

\section{PASCAL FOUCHER}

SRA Midi-Pyrénées, 32 rue de la Dalbade, Toulouse Cedex 6, France -

pascal.foucher@culture.gouv.fr

\section{DOMINIQUE MILLET}

UMR 5199, Université Bordeaux 1, PACEA/PPP, avenue des facultés, 33405 Talence, France prfmillet@orange.fr.

\section{FRANÇOISE MILLET}

13, rue Bordas, 33400 Talence, France - prfmillet@orange.fr 